\title{
EMERGENCY SURGICAL CARE FOR PATIENTS WITH COVID-19 AND TUBERCULOSIS COINFECTION AT MULTISPECIALTY HOSPITAL
}

Reshetnikov MN $\bowtie$, Plotkin DV, Zuban ON, Bogorodskaya EM

Moscow Research and Clinical Center for TB Control, Moscow, Russia

\begin{abstract}
The double burden of the novel coronavirus infection and tuberculosis (TB) is a global challenge. The aspects of emergency surgical care for patients with COVID-19 and TB coinfection remain understudied. The aim of this study was to assess treatment outcomes in acute surgical patients with COVID-19 and preexisting TB coinfection. In 2020, our Center delivered surgical care to 465 patients with COVID-19 and preexisting TB; a total of 64 emergency surgeries were performed on 36 (5.6\%) patients, of whom 16 had HIV. Thirteen patients (36.1\%) were diagnosed with pulmonary TB; 23 patients (63.9\%) had disseminated TB. Chest CT scans showed $>25 \%$ lung involvement in $61.9 \%$ of the patients with COVID-19 pneumonia, $25-50 \%$ lung involvement in $30.6 \%$ of the patients, and $50-75 \%$ lung involvement in $5.6 \%$ of the patients. By performing abdominal CT, we were able to detect abdominal TB complications, including perforated tuberculous ulcers of the intestine, intestinal obstruction and tuberculous peritonitis, as well as tuberculous spondylitis complicated by psoas abscess. Of all surgical interventions, $28.2 \%$ were abdominal, $23.2 \%$ were thoracic, $15.6 \%$ were surgeries for soft tissue infection, and $32.8 \%$ were other types of surgery. Postoperative mortality was $22.2 \%$. We conclude that COVID-19 did not contribute significantly to postoperative mortality among acute surgical patients with TB.
\end{abstract}

Keywords: COVID-19, tuberculosis, HIV, emergency surgery

Author contribution: Reshetnikov MN proposed the concept, collected patient data and wrote the manuscript; Plotkin DV analyzed and interpreted the obtained data, prepared the manuscript and photos for publication; Zuban ON proposed the concept and edited the manuscript; Bogorodskaya EM edited the manuscript and prepared its final version.

Compliance with ethical standards: the study was approved by the Ethics Committee of Moscow Research and Clinical Center for TB Control (Protocol № 10 dated December 17, 2020). Informed consent was obtained from all study participants.

Correspondence should be addressed: Mikhail N. Reshetnikov

Barbolina, 3, Moscow, 107014; taxol@bk.ru

Received: 12.04.2021 Accepted: 19.05.2021 Published online: 31.05.2021

DOI: $10.24075 /$ brsmu.2021.025

\section{ЭКСТРЕННАЯ ХИРУРГИЧЕСКАЯ ПОМОЩЬ БОЛЬНЫМ НОВОЙ КОРОНАВИРУСНОЙ ИНФЕКЦИЕЙ COVID-19 И ТУБЕРКУЛЕЗОМ В МНОГОПРОФИЛЬНОЙ КЛИНИКЕ}

М. Н. Решетников $凶$, Д. В. Плоткин, О. Н. Зубань, Е. М. Богородская

Московский городской научно-практический центр борьбы с туберкулезом, Москва, Россия

\begin{abstract}
Двойное бремя новой коронавирусной инфекции COVID-19 и туберкулеза является одной из глобальных проблем сегодняшнего дня. Мало изучены особенности оказания экстренной хирургической помощи этому контингенту пациентов. Целью исследования было оценить результаты лечения острой хирургической патологии у пациентов с новой коронавирусной инфекцией COVID-19 в сочетании с туберкулезом. За 2020 г. пролечено 465 пациентов с сочетанной инфекцией COVID-19/туберкулез, при этом экстренная хирургическая помощь потребовалась в 36 (5,6\%) случаях, в том числе 16 пациентам с ВИЧ-инфекцией, которым выполнено 64 экстренных оперативных вмешательства. Туберкулез органов дыхания выявлен у 13 $(36,1 \%)$ больных, генерализованный - у 23 (63,9\%). По данным компьютерной томографии (КТ) органов грудной клетки объем вовлечения легочной ткани при вирусной пневмонии COVID-19 менее 25\% зарегистрирован у 61,9\% больных, 25-50\% - у 30,6\%, 50-75\% - у 5,6\%. KT органов брюшной полости позволила выявить осложнения адбоминального туберкулеза (перфорации туберкулезных язв кишечника, острую кишечную непроходимость, туберкулезный перитонит), туберкулезный спондилит, осложненный псоас-абсцессом. Распределение оперативных вмешательств было следующим: 28,2\% - абдоминальных, 23,2\% - торакальных, 15,6\% - при гнойных заболеваниях мягких тканей, 32,8\% - прочих. В послеоперационном периоде летальность составила 22,2\%. По результатам исследования можно сделать вывод, что новая коронавирусная инфекция COVID-19 у пациентов с туберкулезом, подвергнутых экстренным оперативным вмешательсвам, не внесла существенного вклада в увеличение послеоперационной летальности.
\end{abstract}

Ключевые слова: COVID-19, туберкулез, ВИЧ-инфекция, экстренная хирургия

Вклад авторов: М. Н. Решетников - концепция исследования, сбор материала, написание и редактирование текста; Д. В. Плоткин - подготовка текста к печати, редактирование фотограсий, анализ и интерпретация данных; О. Н. Зубань - концепция исследования, редактирование текста; Е. М. Богородская - редактирование и утверждение окончательной версии для публикации.

Соблюдение этических стандартов: исследование одобрено этическим комитетом ГБУЗ Московского научно-практического центра борьбы с туберкулезом (протокол № 10 от 17 декабря 2020 г.). Все пациенты подписали добровольное информированное согласие.

$\bowtie$ Для корреспонденции: Михаил Николаевич Решетников ул. Барболина, д. 3, г. Москва, 107014; taxol@bk.ru

Статья получена: 12.04.2021 Статья принята к печати: 19.05.2021 Опубликована онлайн: 31.05.2021

DOI: $10.24075 /$ vrgmu.2021.025

The COVID-19 pandemic put tremendous strain on public health services, overwhelmed hospital capacities and dramatically increased the workload for healthcare workers. Elective surgeries were postponed due to the implementation of containment measures and hospital repurposing for patients with COVID-19. At the same time, hospitals for infectious diseases were admitting COVID-19 patients with acute surgical conditions, a urologic or gynecologic emergency or trauma [1-4]. During the pandemic, protecting healthcare workers against occupational exposure to the virus became a top priority. SARS-CoV-2 actively replicates in the respiratory and gastrointestinal tracts; this increases the risk of infection through aerosol transmission during gastrointestinal or respiratory tract surgery $[5,6]$. The diagnosis and treatment of the novel coronavirus infection are complicated by misleading symptoms and difficulty implementing international guidelines on operating room practices during the COVID-19 pandemic [7-10]. 
Significant challenges arise when delivering surgical care to patients with COVID-19 and comorbidities, such as tuberculosis [11-14].

The aim of this study was to assess treatment outcomes among acute surgical patients with the novel coronavirus infection and preexisting tuberculosis.

\section{METHODS}

A center for COVID-19 opened at Moscow Research and Clinical Center for Tuberculosis Control of Moscow Healthcare Department on April 16, 2020. The Center has a pulmonary care unit № 4 for COVID-19 patients with TB, as well as radiology, endoscopy, surgical and intensive care units with anesthesiology and critical care experts. In 2020, the Center delivered medical care to 465 patients with TB and COVID-19 coinfection. Of them 36 (5.6\%) patients underwent emergency surgery.

Those 36 patients were included in the study. The following inclusion criterion was applied: patients with COVID-19. TB was confined to the lungs in $13(36.1 \%)$ patients, of whom 8 (61.5\%) had extensive pulmonary TB, 2 (15.4\%) had infiltrative pulmonary TB, 2 (15.4\%) had fibrocavernous TB, and 1 (7.7\%) had caseous pneumonia. Three patients in this subgroup (23.1\%) had HIV coinfection. Disseminated TB involving the lungs and other organs was diagnosed in 23 of 36 patients (63.9\%). In this subgroup, 4 (17.4\%) patients had abdominal TB, 3 (13.0\%) had genitourinary TB; peripheral lymph nodes were involved in $2(8.7 \%)$ cases, 2 more patients $(8.7 \%)$ had bone and joint TB. Multi-organ involvement (>2) was observed in $12(52.2 \%)$ patients. In the disseminated TB subgroup, HIV coinfection was detected in 13 (56.5\%) patients.

Therapeutic interventions for COVID-19 were conducted following the COVID-19 Treatment Protocol for patients undergoing treatment at healthcare facilities of Moscow Healthcare Department (Moscow, 2020). TB treatment protocols complied with the Federal Clinical Guidelines on treating TB in adults (Moscow, 2020).

Twenty-three (63.9\%) patients were referred to the Center by specialized TB hospitals of Moscow City. Thirteen patients $(36.1 \%)$ were transferred by emergency medical services (EMS) from other medical facilities. Of them, 7 came from non-TB facilities due to suspicion of TB, 6 were taken by EMS either from a computed tomography facility or from their homes. Nineteen (52.8\%) patients were Moscow City residents, 9 (25.0\%) resided outside Moscow region, 5 (13.9\%) were nonRussian residents, and 3 (8.3\%) were homeless.

The study included 31 (86.1\%) male and 5 (13.9\%) female patients aged 26 to 83 years (mean age was $41.9 \pm 15.3$ years). All of them had TB; 16 (44.4\%) had HIV coinfection. On admission, all patients underwent a computed tomography (CT) scan of the chest; in addition, patients with acute abdominal pathology underwent an abdominal CT and/or abdominal ultrasound examination. The clinical diagnosis of COVID-19 was based on PCR tests for SARS-CoV-2 detection in nasopharyngeal swabs and chest CT findings. TB diagnosis was based on radiography findings, urine, sputum and stool tests, and biopsies. The collected specimens were studied for the pathomorphological features of TB and/or the presence of tuberculosis mycobacteria (MTB) using luminescence microscopy, liquid/solid culture-based methods and moleculargenetic analysis.

The significance of differences between quantitative variables was assessed using Student's t-test. For quantitative variables, the chi-square test was used.

\section{RESULTS}

The average duration of TB from its onset to the time of hospital admission was 6.7 months. Sputum tests came back negative for most patients (23 patients, or 63.9\%). Thirteen patients (36.1\%) tested positive for MTB; of them 4 (30.8\%) were infected with MDR strains and 1 (7.7\%) had XDR-TB.

In all cases, chest CT scans were suggestive of viral pneumonia. SARS-CoV-2 RNA was detected in the nasopharyngeal swabs of $28(77.8 \%)$ patients; 8 (22.2\%) tested negative for SARS-CoV-2, so the diagnosis of COVID-19 in these patients was based on the clinical and radiographic findings (Table 1).

Abdominal CT was performed on 11 (30.6\%) patients. Two patients had free gas in the peritoneal cavity due to a perforated tuberculous ulcer of the ileum. In another patient, the accumulation of free gas was localized to the right ileal region and was due to the sealed perforation of the cecum. One patient had retroperitoneal abscess due to the retroperitoneal perforation of a tuberculous ulcer in the cecum. One patient had dilated bowel loops resulting from acute intestinal obstruction. Abdominal lymphadenopathy and encysted tuberculous peritonitis were observed in 2 patients. One patient had tense ascites and another one had tuberculous spondylitis complicated by psoas abscess. Two patients with strangulated hernia had no abdominal pathology.

A total of 64 emergency surgeries were performed on 36 patients; 12 patients required repeat surgery (Table 2).

Abdominal surgery was the most common surgical intervention: a total of 18 (28.2\%) abdominal surgeries were performed on 8 patients. Five patients underwent surgery for abdominal TB complications: 4 of them had a perforated tuberculous intestinal ulcer due to intestinal TB, one had acute intestinal obstruction due to a stenosing ulcer. It should be noted that abdominal surgical pathology is often characterized by a protracted clinical course and vague symptoms, and the patient starts seeking medical advice after the condition has progressed to advanced stages and requires a series of surgical interventions. Four patients with a perforated tuberculous ulcer of the intestine had to undergo repeat surgery. The patient with acute intestinal obstruction was treated with only one surgery.

Two patients with pulmonary TB and COVID-19 coinfection were admitted to the Center for suspected acute appendicitis. Diagnostic laparoscopy revealed that one of them had

Table 1. Distribution of patients with TB by the severity of viral pneumonia and the presence of SARS-CoV-2 RNA

\begin{tabular}{|c|c|c|c|c|}
\hline \multirow{2}{*}{$\begin{array}{c}\text { Severity of viral pneumonia on chest CT } \\
\text { (lung involvement score) }\end{array}$} & Abs. & \multicolumn{2}{|c|}{ SARS-CoV-2 RNA detected } \\
\cline { 2 - 5 } & 23 & 61.9 & Abs. \\
\hline $1(<25 \%)$ & 11 & 30.6 & 52.8 \\
\hline $2(25-50 \%)$ & 2 & 5.6 & 8 \\
\hline $3(50-75 \%)$ & 36 & 100 & 19 \\
\hline Total & 22.2 & 28 \\
\hline
\end{tabular}


Table 2. Number and type of performed surgical interventions

\begin{tabular}{|c|c|c|c|c|}
\hline \multirow{2}{*}{ Intervention } & \multicolumn{2}{|c|}{ Number } & \multicolumn{2}{|c|}{ Deaths $(n=36)$} \\
\hline & Abs. & $\%$ & Abs. & $\%$ \\
\hline \multicolumn{5}{|c|}{ Abdominal } \\
\hline Relaparotomy for peritonitis & 12 & 18.8 & & \\
\hline Right hemicolectomy & 3 & 4.7 & & \\
\hline Diagnostic laparoscopy & 2 & 3.1 & & \\
\hline Abdominal paracentesis & 1 & 1.6 & & \\
\hline Total: & 18 & 28.2 & 4 & 11.1 \\
\hline \multicolumn{5}{|c|}{ Thoracic } \\
\hline Pleural drainage & 11 & 17.2 & & \\
\hline Bronchoscopy, bronchial blocker placement & 4 & 6.2 & & \\
\hline Total: & 15 & 23.4 & & \\
\hline \multicolumn{5}{|c|}{ Surgery for soft tissue infection } \\
\hline Necrectomy & 5 & 7.8 & & \\
\hline VAC procedure & 3 & 4.7 & & \\
\hline Incision and drainage surgery for phlegmon & 2 & 3.1 & & \\
\hline Total: & 10 & 15.6 & & \\
\hline \multicolumn{5}{|c|}{ Other } \\
\hline Tracheostomy & 7 & 10.9 & & \\
\hline Secondary suture & 4 & 6.2 & & \\
\hline Primary wound debridement & 3 & 4.7 & & \\
\hline Suprapubic cystostomy & 3 & 4.7 & & \\
\hline Herniotomy for strangulated hernia & 2 & 3.1 & & \\
\hline Psoas abscess drainage & 1 & 1.6 & & \\
\hline Lower limb amputation & 1 & 1.6 & & \\
\hline Total: & 21 & 32.8 & 4 & 11.1 \\
\hline Total: & 64 & 100 & 8 & 22.2 \\
\hline
\end{tabular}

tuberculosis of abdominal lymph nodes and another had tuberculous peritonitis resulting from the spread of the disease from the lungs to other organs. Intraoperatively, multiple miliary lesions of the peritoneum, bowel loops, liver and spleen, abdominal lymphadenopathy, and peritoneal effusion were observed. In both cases, abdominal tuberculosis was confirmed by the histopathologic examination of the biopsied abdominal lymph nodes and peritoneal specimens.

Thoracic surgery was performed on 10 patients with COVID-19 and preexisting TB; of them 5 had to undergo repeat surgery. All thoracic patients received pleural drains (6 patients required drains due to pneumothorax, the rest 4 had pleuritis or pleural empyema; see Figure).

Bronchial blocker placement during rigid bronchoscopy and mechanical ventilation was performed on 4 patients. Of them, 2 had fibrocavernous TB and developed pulmonary hemorrhage. Two other patients had a bronchopleural fistula, a collapsed lung and were unresponsive to pleural drainage. Tracheostomy was performed on 7 patients in intensive care requiring long-term mechanical ventilation.

There were $8(22.2 \%)$ postoperative deaths. Of them, 4 patients with COVID-19/TB and respiratory failure were put on a ventilator and so underwent only one surgical intervention (tracheostomy). In their case, the immediate cause of death was COVID-19 and TB coinfection. Of those 4 patients, 2 had extensive pulmonary TB and COVID-19 coinfection (lung involvement score: 3 ); the other 2 patients had disseminated TB and COVID-19 coinfection (lung involvement score: 1 and 3 , respectively).
Two patients died after multiple surgical interventions for abdominal TB complications, perforated tuberculous ulcers of the intestine accompanied by peritonitis. One patient, who underwent diagnostic laparoscopy for TB peritonitis, died of disseminated TB. Another death was due to decompensated liver cirrhosis and disseminated TB; this patient had tight ascites and had to undergo abdominal paracentesis. Four (50\%) of the deceased patients had triple infection: COVID-19/HIV/TB; of them 2 also had hepatitis C.

\section{DISCUSSION}

There are a few important aspects to diagnosing and treating acute surgical patients with COVID-19 and TB coinfection. Before the COVID-19 pandemic, an abdominal ultrasound examination was the preferred diagnostic modality for patients with acute abdomen [15]. Now, considering the spread of the novel coronavirus infection, it is essential to assess the extent of lung damage caused not only by TB but also by rapidly progressing COVID-19 pneumonia [16]. We think that performing both chest and abdomen CT in patients with coinfection helps to clarify the underlying cause of abdominal pathology and detect an abdominal catastrophe if presenting symptoms are unobvious. Our opinion is consistent with the opinion of other researchers $[17,18]$.

However, some authors report that abdominal CT examinations are being decreasingly performed on patients with acute abdomen because CT facilities are overwhelmed during the pandemic; such reports promote laparoscopy as a 


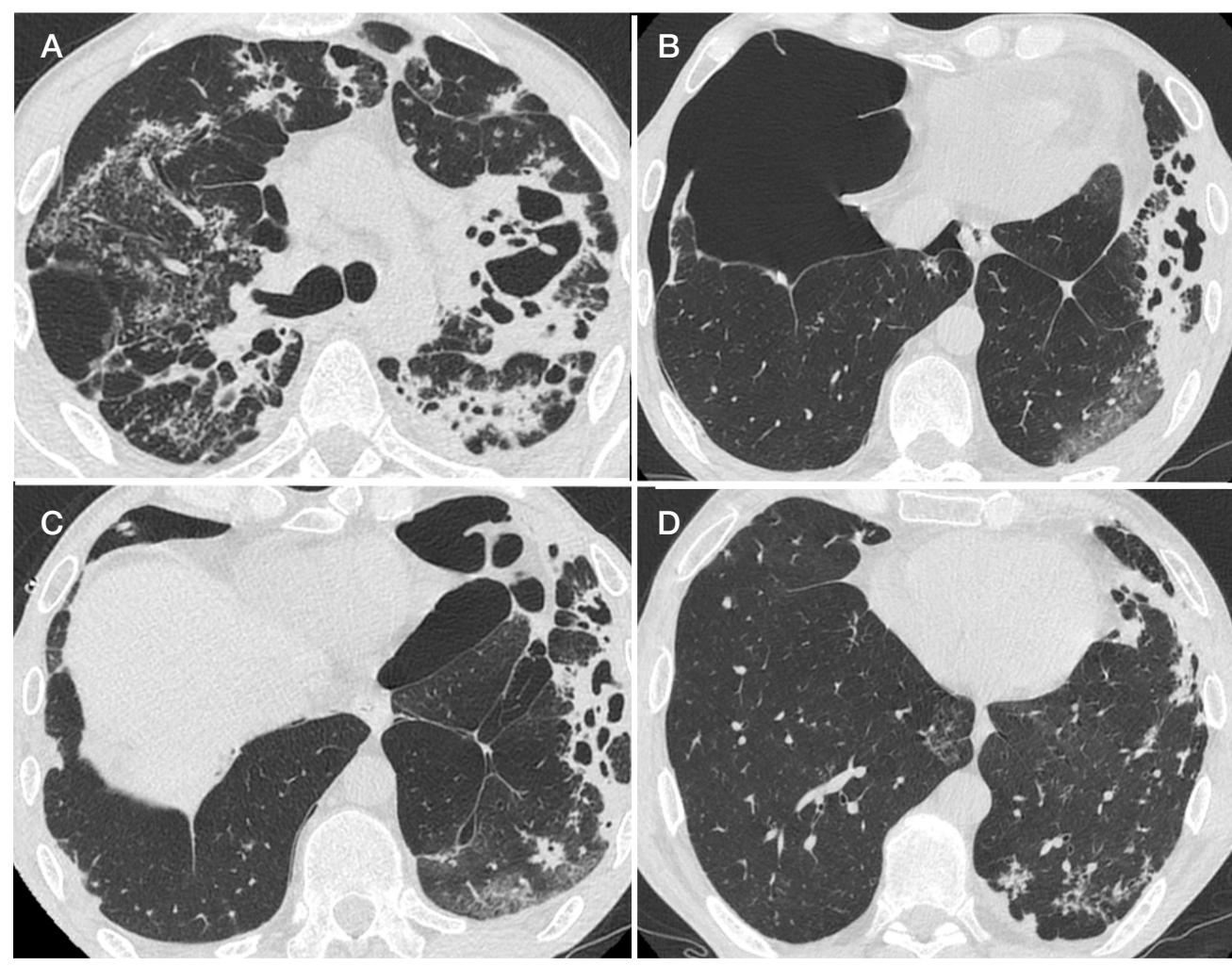

Fig. Chest CT scans. Pneumothorax dynamics. A. Date of exam: 18.11.2020. Focal infiltrates and various-sized cavities in both lungs. B. Date of exam: 20.11 .2020$. Right-sided pneumothorax. Ground glass opacities in left S10 (> 25\% lung involvement). C. Date of exam: 22.11.2020. Scan performed after right pleural drainage; the lung is almost completely expanded. Left-sided pneumothorax; partially resolved ground glass opacities in left S10. D. Date of exam: 11.12.2020. Complete resolution of pneumothorax; partially resolved infiltrates

diagnostic modality for patients with acute abdomen [19, 20]. However, patients mentioned in these publications do not have TB. It is well known that abdominal CT can clarify the need for laparoscopy as it is capable of detecting free gas in the peritoneum and fluid accumulation in bowel loops. In other words, abdominal CT can noninvasively detect complications of abdominal TB, including perforated tuberculous ulcers and acute intestinal obstruction. Therefore, we think it reasonable to perform an abdominal CT scan on patients with suspected acute surgical pathology and COVID-19/TB coinfection. In our study, only 2 patients, whose CT scans were inconclusive, were subjected to diagnostic laparoscopy. But the overarching surgical treatment strategy for our patients with abdominal TB complications was unchanged [21, 22].

Pulmonary TB is a common cause of spontaneous pneumothorax. The rate of this complication varies between $0.6 \%$ and $1.4 \%$ [23]. In patients with TB, spontaneous pneumothorax develops due to ruptured pleural blebs or bullae compromising visceral pleura integrity. However, spontaneous pneumothorax is not always associated with TB in TB patients. For example, it can be linked to bullous emphysema which developed independently of TB. Recent publications report spontaneous pneumothorax in patients with COVID-19 who did not have TB and/or any other preexisting lung disease. Almost all of them were on mechanical ventilation, i.e. they might have sustained injury to the trachea during intubation. Their mortality rate was very high (72.7\%) [24-26]. In our study, 6 of 7 patients with pneumothorax underwent pleural drainage. All of them had active pulmonary TB. One of them died: he had a past history of multiple surgeries for abdominal TB complications and pneumothorax.

The analysis of surgical interventions performed in April through December 2019 vs. the same period in 2020 reveals a rise in the total share of tracheostomies from 5.1\% (12 of 234 emergency surgeries) in 2019 to $10.9 \%$ in 2020, which can be explained by the need for long-term mechanical ventilation in patients with COVID-19.

The analysis of postoperative mortality shows that abdominal TB complications (perforated tuberculous ulcer leading to peritonitis in patients with disseminated TB) was the primary cause of death in 50\% of patients in 2019 and 2020. A multicenter cohort study reports an increase in postoperative mortality to $15.9 \%$ among COVID-19 patients requiring emergency surgical care, in comparison with patients without the novel coronavirus infection [27].

In our study, there was no reliable increase in postoperative mortality: $16.5 \%$ in 2019 vs. $22.2 \%$ in $2020\left(\chi^{2}=0.46\right.$; $p=0.49$ ). Therefore, we conclude that COVID-19 did contribute significantly to postoperative mortality in acute surgical patients with TB. According to the literature, hospital mortality from COVID-19 varies from $6 \%$ to $25 \%$ [28]. Previously, we reported that overall hospital mortality among patients with COVID-19 and TB coinfection was $10.2 \%$, whereas postoperative mortality in this cohort of patients was more than twice as high (22.2\%) [14].

One of the limitations of this study is its small sample size due to the specific character of our patient cohort (triple COVID-19/HIV/TB infection). Another limitation is the short follow-up period, which did not allow us to analyze the longterm outcomes of the performed surgical interventions.

\section{CONCLUSION}

At our specialized TB hospital providing a wide range of health services to TB patients, emergency surgery was most commonly performed on patients with disseminated TB and COVID-19 coinfection (63.9\%); patients with pulmonary TB required emergency surgical care less often (36.1\%). Almost half of our 
patients admitted during the pandemic for surgical emergency (44.4\%) had triple infection (COVID-19/HIV/TB). Abdominal surgery (28.2\%) was the most commonly performed procedure among patients with COVID-19/TB, followed by thoracic surgery (23.4\%) and surgery for soft tissue infection (15.6\%).
The highest postoperative mortality (50\%) was observed in the small group of 8 patients operated for abdominal conditions. Of all the patients who died in the postoperative period, 2 (50\%) had COVID-19 and TB, and another 2 (50\%) had quadruple infection with COVID-19, HIV, TB and hepatitis C.

\section{References}

1. Patriti A, Baiocchi GL, Catena F, Marini P, Catarci M; FACS on behalf of the Associazione Chirurghi Ospedalieri Italiani (ACOI). Emergency general surgery in Italy during the COVID-19 outbreak: first survey from the real life. World J Emerg Surg. 2020; 15 (1): 36 PubMed PMID: 32448333. DOI: 10.1186/s13017-020-00314-3.

2. De Simone B, Chouillard E, Di Saverio S, Pagani L, Sartelli M, Biffl WL et al. Emergency surgery during the COVID-19 pandemic: what you need to know for practice. Ann R Coll Surg Engl. 2020; 102 (5): 323-332. PubMed PMID: 32352836. DOI: 10.1308/ rcsann.2020.0097.

3. Colosimo C, Kelly J, Coker J, Bhuller S, Ballman E, Baker-Sparret C, et al. Unscreened: Urgent and Emergent Surgical Outcomes in the Early COVID-19 Pandemic. Cureus. 2020; 12 (12): e11878. PubMed PMID: 33415031. DOI: 10.7759/cureus.11878.

4. Krutsri $C$, Singhatas $P$, Sumpritpradit $P$, Thampongsa $T$, Phuwapraisirisan S, Gesprasert C, et al. Impact of the COVID-19 pandemic on the outcome, morbidity, and mortality of acute care surgery patients: A retrospective cohort study. International Journal of Surgery Open. 2021; (28): 50-55. DOI: 10.1016/j. ijso.2020.11.021.

5. Gupta A, Madhavan MV, Sehgal K, Nair N, Mahajan S, Sehrawat TS, et al. Extrapulmonary manifestations of COVID-19. Nat Med. 2020; 26 (7): 1017-32. PubMed PMID: 32651579. DOI: 10.1038/ s41591-020-0968-3.

6. Maev IV, Shpektor AV, Vasilyeva EY, Manchurov VN, Andreev DN Novel coronavirus infection COVID-19: extrapulmonary manifestations. Ter Arkh. 2020; 92 (8): 4-11. PubMed PMID: 33346454. DOI: 10 .26442/00403660.2020.08.000767. Russian.

7. Ti LK, Ang LS, Foong TW, Ng BSW. What we do when a COVID-19 patient needs an operation: operating room preparation and guidance. Can J Anaesth. 2020; 67 (6): 756-58. PubMed PMID: 32144591. DOI: 10.1007/s12630-020-01617-4.

8. COVIDSurg Collaborative. Global guidance for surgical care during the COVID-19 pandemic. Br J Surg. 2020; 107 (9): $1097-$ 03. PubMed PMID: 32293715. DOI: 10.1002/bjs.11646.

9. Welsh Surgical Research Initiative (WSRI) Collaborative. Recommended operating room practice during the COVID-19 pandemic: systematic review. BJS Open. 2020; 4 (5): 748-56. PubMed PMID: 32395909. DOI: 10.1002/bjs5.50304.

10. Gote SV, Revishvili ASh, Pushkar DYu, Adamyan LV, Krylov W Shelygin YuA, i dr. Metodicheskie rekomendacii "Jekstrennaja hirurgicheskaja pomoshh' v uslovijah COVID-19". M., 2020. Availabe from: https://главный-хирург.pф/docs/metodrec/covid19-recommendation.pdf [Accessed Apr 10, 2021]. Russian.

11. Tadolini M, Codecasa LR, García-García JM, Blanc FX, Borisov S, Alffenaar JW, et al. Active tuberculosis, sequelae and COVID-19 co-infection: first cohort of 49 cases. Eur Respir J. 2020; 56 (1): 2001398. PubMed PMID: 32457198. DOl: 10.1183/13993003.01398-2020.

12. Elkin AV, Savina TA, Levina LR, Kovaleva RG, Kondakova MN. Mnogoprofil'nyj tuberkuleznyj stacionar goroda Sankt-Peterburga v period pandemii COVID-19. Tuberkulez i social'no znachimye zabolevanija. 2020; (4): 10-15. Russian.

13. Gao Y, Liu M, Chen Y, Shi S, Geng J, Tian J. Association between tuberculosis and COVID-19 severity and mortality: A rapid systematic review and meta-analysis. J Med Virol. 2020; 10.1002/ jmv.26311. PubMed PMID: 32687228. DOI: 10.1002/jmv.26311.

14. Zuban ON, Reshetnikov MN, Ustinov AV. COVID-19 u bol'nyh tuberkulezom: odnocentrovoe issledovanie. Tuberkulez i social'no znachimye zabolevanija. 2020; (4): 58-63. Russian.

15. Plotkin DV, Loshkareva EO, Kirillova OV, Reshetnikov $\mathrm{MH}$, Sinicyn MV, Chauzov AYu. Jeho-sonograficheskaja semiotika abdominal'nogo tuberkuleza. Tuberkulez i bolezni legkih. 2020; 98 (8): 32-38. DOI: 10.21292/2075-1230-2020-98-8-32-38. Russian.

16. Petrikov SS, Popugaev KA, Barmina TG, Zabavskaja OA, Sharifullin FA, Kokov LS. Sopostavlenie klinicheskih dannyh i komp'juternotomograficheskoj semiotiki legkih pri COVID-19. Tuberkulez i bolezni legkih. 2020; 98 (7): 14-25. DOl: 10.21292/2075-1230-2020-98-714-25. Russian.

17. Borofsky S, Taffel M, Khati N, Zeman R, Hill M. The emergency room diagnosis of gastrointestinal tract perforation: the role of CT. Emerg Radiol. 2015; 22 (3): 315-27. PubMed PMID: 25417073. DOI: 10.1007/s10140-014-1283-4.

18. Deshpande SS, Joshi AR, Deshpande SS, Phajlani SA. Computed tomographic features of abdominal tuberculosis: unmask the impersonator! Abdom Radiol (NY). 2019; 44 (1): 11-21. PubMed PMID: 30027495. DOI: 10.1007/s00261-018-1700-3.

19. Korolkov AYu, Teplov VM, Zajcev DA, Cebrovskaja EA, Nikitina TO. Okazanie jekstrennoj hirurgicheskoj pomoshhi v uslovijah mnogoprofil'nogo stacionara, pereprofilirovannogo pod lechenie pacientov s novoj koronavirusnoj infekciej (COVID-19). Vestnik hirurgii imeni I. I. Grekova. 2020; 179 (5): 11-15. DOI: 10.24884/0042-4625-2020-179-5-11-15. Russian.

20. Vechorko VI, Anosov VD, Silaev BV. Diagnosis and treatment of acute surgical diseases in patients with COVID-19. Bulletin of RSMU. 2020; (3): 65-69. DOI: 10.24075/brsmu.2020.038.

21. Reshetnikov MN, Skopin MS, Sinicyn MV, Plotkin DV, Zuban ON. Vybor hirurgicheskoj taktiki pri perforativnyh tuberkuleznyh jazvah kishechnika u bol'nyh VICh-infekciej. Tuberkulez i bolezni legkih. 2017: 95 (9): 19-24. DOI: 10.21292/2075-1230-2017-95-9-1924. Russian.

22. Gerstein S, Khatri A, Roth N, Wallach F. Coronavirus disease 2019 and extra-pulmonary tuberculosis co-infection - A case report and review of literature. J Clin Tuberc Other Mycobact Dis. 2021; 22: 100213. PubMed PMID: 33521333. DOI: 10.1016/j. jctube.2021.100213.

23. Freixinet JL, Caminero JA, Marchena J, Rodríguez PM, Casimiro JA, Hussein M. Spontaneous pneumothorax and tuberculosis: longterm follow-up. Eur Respir J. 2011; 38 (1): 126-31. PubMed PMID: 20947681. DOI: 10.1183/09031936.00128910.

24. Miheev AB, Aftaeva EV, Kazakova SS, Zinoveva ZV, Gavrikova NV. Spontannyj pnevmotoraks kak oslozhnenie porazhenija legkih pri COVID-19. Tuberkulez i bolezni legkih. 2021; 99 (3): 18-22. DOI: 10.21292/2075-1230-2021-99-3-18-22. Russian.

25. $\mathrm{Xu} \mathrm{Y}, \mathrm{Li} \mathrm{S}$, Liu H. Clinical outcomes of pleural drainage on pneumothorax and hydrothorax in critically ill patients with COVID-19: A case series with literature review. Heart \& Lung. 2020; 50 (2): 213-19. PubMed PMID: 33310504. DOI: 10.1016/j. hrtlng.2020.12.007.

26. Martinelli AW, Ingle T, Newman J, Nadeem I, Jackson K, Lane ND, et al. COVID-19 and pneumothorax: a multicentre retrospective case series. Eur Respir J. 2020; 56 (5): 2002697. PubMed PMID: 32907891. DOI: 10.1183/13993003.02697-2020.

27. Carrier FM, Amzallag É, Lecluyse V, Côté G, Couture ÉJ, D'Aragon F, et al. Postoperative outcomes in surgical COVID-19 patients: a multicenter cohort study. BMC Anesthesiol. 2021; 21 (1): 15. PubMed PMID: 33435887. DOI: 10.1186/s12871-02101233-9.

28. Li J, Huang DQ, Zou B, Yang H, Hui WZ, Rui F, et al. Epidemiology of COVID-19: A systematic review and meta-analysis of clinical characteristics, risk factors, and outcomes. J Med Virol. 2021; 93 (3): 1449-58. PubMed PMID: 32790106. DOI: 10.1002/ jmv.26424. 
1. Patriti A, Baiocchi GL, Catena F, Marini P, Catarci M; FACS on behalf of the Associazione Chirurghi Ospedalieri Italiani (ACOI). Emergency general surgery in Italy during the COVID-19 outbreak: first survey from the real life. World J Emerg Surg. 2020; 15 (1): 36. PubMed PMID: 32448333. DOI: 10.1186/s13017-020-00314-3.

2. De Simone B, Chouillard E, Di Saverio S, Pagani L, Sartelli M, Biffl WL et al. Emergency surgery during the COVID-19 pandemic: what you need to know for practice. Ann R Coll Surg Engl. 2020; 102 (5): 323-332. PubMed PMID: 32352836. DOI: 10.1308/ rcsann.2020.0097.

3. Colosimo C, Kelly J, Coker J, Bhuller S, Ballman E, Baker-Sparret C, et al. Unscreened: Urgent and Emergent Surgical Outcomes in the Early COVID-19 Pandemic. Cureus. 2020; 12 (12): e11878. PubMed PMID: 33415031. DOI: 10.7759/cureus.11878.

4. Krutsri $C$, Singhatas $P$, Sumpritpradit $P$, Thampongsa $T$, Phuwapraisirisan S, Gesprasert C, et al. Impact of the COVID-19 pandemic on the outcome, morbidity, and mortality of acute care surgery patients: A retrospective cohort study. International Journal of Surgery Open. 2021; (28): 50-55. DOI: 10.1016/j. ijso.2020.11.021.

5. Gupta A, Madhavan MV, Sehgal K, Nair N, Mahajan S, Sehrawat TS, et al. Extrapulmonary manifestations of COVID-19. Nat Med. 2020; 26 (7): 1017-32. PubMed PMID: 32651579. DOI: 10.1038/ s41591-020-0968-3.

6. Маев И. В., Шпектор А. В., Васильева Е. Ю., Манчуров В. Н., Андреев Д. Н. Новая коронавирусная инфекция COVID-19: экстрапульмональные проявления. Терапевтический архив. 2020; 92 (8): 4-11. DOI: 10.26442/00403660.2020.08.000767.

7. Ti LK, Ang LS, Foong TW, Ng BSW. What we do when a COVID-19 patient needs an operation: operating room preparation and guidance. Can J Anaesth. 2020; 67 (6): 756-58. PubMed PMID: 32144591. DOI: 10.1007/s12630-020-01617-4.

8. COVIDSurg Collaborative. Global guidance for surgical care during the COVID-19 pandemic. Br J Surg. 2020; 107 (9): $1097-$ 03. PubMed PMID: 32293715. DOI: 10.1002/bjs.11646.

9. Welsh Surgical Research Initiative (WSRI) Collaborative. Recommended operating room practice during the COVID-19 pandemic: systematic review. BJS Open. 2020; 4 (5): 748-56. PubMed PMID: 32395909. DOI: 10.1002/bjs5.50304.

10. Готье С. В., Ревишвили А. Ш., Пушкарь Д. Ю., Адамян Л. В., Крылов В. В., Шелыгин Ю. А. и др. Методические рекомендации «Экстренная хирургическая помощь в условиях COVID-19». М., 2020; 14 с. Доступно по ссылке: https://главный-хирург.рф/docs/metodrec/covid-19recommendation.pdf [Дата обращения 10 апреля 2021 г.]

11. Tadolini M, Codecasa LR, García-García JM, Blanc FX, Borisov S, Alffenaar JW, et al. Active tuberculosis, sequelae and COVID-19 co-infection: first cohort of 49 cases. Eur Respir J. 2020; 56 (1): 2001398. PubMed PMID: 32457198. DOI: 10.1183/13993003.01398-2020.

12. Елькин А. В., Савина Т. А., Левина Л. Р., Ковалева Р. Г., Кондакова М. Н. Многопрофильный туберкулезный стационар города Санкт-Петербурга в период пандемии COVID-19. Туберкулез и социально значимые заболевания. 2020; (4): 10-15.

13. Gao Y, Liu M, Chen Y, Shi S, Geng J, Tian J. Association between tuberculosis and COVID-19 severity and mortality: A rapid systematic review and meta-analysis. J Med Virol. 2020; 10.1002/ jmv.26311. PubMed PMID: 32687228. DOI: 10.1002/jmv.26311.

14. Зубань О. Н., Решетников М. Н., Устинов А. В. COVID-19 у больных туберкулезом: одноцентровое исследование. Туберкулез и социально значимые заболевания. 2020; (4): 58-63.

15. Плоткин Д. В., Лошкарева Е. О., Кириллова О. В., Решетников М. Н., Синицын М. В., Чаузов А. Ю. Эхо-сонографическая семиотика абдоминального туберкулеза. Туберкулез и болезни легких. 2020; 98 (8): 32-38. DOI: 10.21292/20751230-2020-98-8-32-38.

16. Петриков С. С., Попугаев К. А., Бармина Т. Г., Забавская О. А., Шарифуллин Ф. А., Коков Л. С. Сопоставление клинических данных и компьютерно-томографической семиотики легких при COVID-19. Туберкулез и болезни легких. 2020; 98 (7): 14-25. DOI: 10.21292/2075-1230-2020-98-7-14-25.

17. Borofsky S, Taffel M, Khati N, Zeman R, Hill M. The emergency room diagnosis of gastrointestinal tract perforation: the role of CT. Emerg Radiol. 2015; 22 (3): 315-27. PubMed PMID: 25417073. DOI: $10.1007 / \mathrm{s} 10140-014-1283-4$.

18. Deshpande SS, Joshi AR, Deshpande SS, Phajlani SA. Computed tomographic features of abdominal tuberculosis: unmask the impersonator! Abdom Radiol (NY). 2019; 44 (1): 11-21. PubMed PMID: 30027495. DOI: 10.1007/s00261-018-1700-3.

19. Корольков А. Ю., Теплов В. М., Зайцев Д. А., Цебровская Е. А. Никитина Т. О. Оказание экстренной хирургической помощи в условиях многопрофильного стационара, перепрофилированного под лечение пациентов с новой коронавирусной инфекцией (COVID-19). Вестник хирургии имени И. И. Грекова. 2020; 179 (5): 11-15. DOI: 10.24884/00424625-2020-179-5-11-15.

20. Вечорко В. И., Аносов В. Д., Силаев Б. В. Диагностика и лечение острых хирургических заболеваний у пациентов с COVID-19. Вестник PГMУ. 2020; (3): 71-76. DOI: 10.24075/ vrgmu.2020.038.

21. Решетников М. Н., Скопин М. С., Синицын М. В., Плоткин Д. В., Зубань О. Н. Выбор хирургической тактики при перфоративных туберкулезных язвах кишечника у больных ВИЧ-инфекцией. Туберкулез и болезни легких. 2017; 95 (9): 19-24. DOI: 10.21292/2075-1230-2017-95-9-19-24.

22. Gerstein S, Khatri A, Roth N, Wallach F. Coronavirus disease 2019 and extra-pulmonary tuberculosis co-infection - A case report and review of literature. J Clin Tuberc Other Mycobact Dis. 2021; 22: 100213. PubMed PMID: 33521333. DOI: 10.1016/j. jctube.2021.100213

23. Freixinet JL, Caminero JA, Marchena J, Rodríguez PM, Casimiro JA, Hussein M. Spontaneous pneumothorax and tuberculosis: longterm follow-up. Eur Respir J. 2011; 38 (1): 126-31. PubMed PMID: 20947681. DOI: 10.1183/09031936.00128910.

24. Михеев А. В., Афтаева Е. В., Казакова С. С., Зиновьева З. В., Гаврикова Н. В. Спонтанный пневмоторакс как осложнение поражения легких при COVID-19. Туберкулез и болезни легких. 2021; 99 (3): 18-22. DOI: 10.21292/2075-1230-202199-3-18-22

25. $\mathrm{Xu} \mathrm{Y,} \mathrm{Li} \mathrm{S,} \mathrm{Liu} \mathrm{H.} \mathrm{Clinical} \mathrm{outcomes} \mathrm{of} \mathrm{pleural} \mathrm{drainage} \mathrm{on}$ pneumothorax and hydrothorax in critically ill patients with COVID-19: A case series with literature review. Heart \& Lung. 2020; 50 (2): 213-19. PubMed PMID: 33310504. DOI: 10.1016/j. hrtlng.2020.12.007.

26. Martinelli AW, Ingle T, Newman J, Nadeem I, Jackson K, Lane ND, et al. COVID-19 and pneumothorax: a multicentre retrospective case series. Eur Respir J. 2020; 56 (5): 2002697. PubMed PMID: 32907891. DOI: 10.1183/13993003.02697-2020.

27. Carrier FM, Amzallag É, Lecluyse V, Côté G, Couture ÉJ, D'Aragon F, et al. Postoperative outcomes in surgical COVID-19 patients: a multicenter cohort study. BMC Anesthesiol. 2021; 21 (1): 15. PubMed PMID: 33435887. DOI: 10.1186/s12871-02101233-9.

28. Li J, Huang DQ, Zou B, Yang H, Hui WZ, Rui F, et al. Epidemiology of COVID-19: A systematic review and meta-analysis of clinical characteristics, risk factors, and outcomes. J Med Virol. 2021; 93 (3): 1449-58. PubMed PMID: 32790106. DOI: 10.1002/ imv.26424. 